\title{
HUBUNGAN ANTARA MINAT BELAJAR DAN KEBIASAAN BELAJAR TERHADAP HASIL BELAJAR KIMIA SISWA KELAS XI IPA SMA MATARAM TAHUN AJARAN 2017/2018
}

\author{
Elly Verawati Amin', Yayuk Andayani ${ }^{2}$, Sukib Sukib ${ }^{2}$ \\ 1 Mahasiswa Prodi Pendidikan Kimia FKIP Universitas \\ Mataram,Indonesia 2 Dosen Prodi Pendidikan Kimia FKIP Universitas \\ Mataram, Indonesia Email: ellyvera2@gmail.com
}

\begin{abstract}
Abstrak
Penelitian ini bertujuan untuk mengetahui (1) hubungan antara minat belajar terhadap hasil belajar kimia, (2) hubungan antara kebiasaan belajar terhadap hasil belajar kimia, (3) hubungan antara minat belajar dan kebiasaan belajar secara bersama-sama terhadap hasil belajar kimia. Jenis penelitian ini merupakan penelitian kuantitatif dengan rancangan penelitian korelasional. Sampel sebanyak 170 siswa, diambil dengan teknik proportionate stratified random sampling. Data minat belajar dan kebiasaan belajar diperoleh melalui angket dan hasil belajar siswa diperoleh melalui dokumentasi. Teknik analisis data menggunakan analisis korelasi sederhana, analisis korelasi ganda, analisis regresi sederhana dan analisis regresi ganda. Hasil penelitian menunjukkan bahwa pada taraf signifikan 5\%: (1) terdapat hubungan yang positif dan signifikan antara minat belajar terhadap hasil belajar kimia siswa yang ditunjukkan oleh nilai $\mathrm{r}_{\text {hitung }}$ $=0,518$ lebih besar dari $r_{\text {tabel }}=0,159$, (2) terdapat hubungan yang positif dan signifikan antara kebiasaan belajar terhadap hasil belajar kimia siswa yang ditunjukkan oleh nilai $r_{\text {hitung }}=0,476$ lebih besar dari $\mathrm{r}_{\text {tabel }}=0,159$, (3) terdapat hubungan yang positif dan signifikan antara minat belajar dan kebiasaan belajar secara bersama-sama terhadap hasil belajar kimia siswa yang dibuktikan oleh nilai $\mathrm{F}_{\text {hitung }}=32,11$ lebih besar dari $\mathrm{F}_{\text {tabel }}=3,06$.
\end{abstract}

Kata Kunci: minat belajar, kebiasaan belajar, hasil belajar kimia.

\section{THE RELATIONSHIP BETWEEN LEARNING INTERESTS AND LEARNING HABITS TOWARDS LEARNING ACHIEVEMENTS IN CHEMISTRY OF XI SCIENCE STUDENTS OF SENIOR HIGH SCHOOL IN MATARAM ACADEMIC YEAR 2017/2018}

\begin{abstract}
This study aimed to investigate: 1) the relationship between learning interests and learning achievements in chemistry; 2) the relationship between learning habits and learning achievements in chemistry; 3) the relationship of both learning interests and learning habits towards learning achievements in chemistry. This is a quantitative research with correlational design. The sample of the study involved 170 students who were selected using proportionate stratified random sampling technique. Data of the learning interests and learning habits were collected using questionnaires, while the learning achievements in chemistry was obtained from the records of students' performance in the final exam of odd semester of the academic year 2017/2018. The data were analyzed using single correlation analysis, multiple correlation analysis, single regression analysis, and multiple regression analysis. The results showed that at 5\% error of significance level: (1) there was a positive and significant relationship between learning interests and learning achievements in chemistry in which $r_{\text {count }}(0.518)>r_{\text {table }}(0.159)$,

(2) there was a positive and significant relationship between learning habits towards learning achievements in chemistry as $r_{\text {count }}(0.476)>r_{\text {table }}(0.159)$, and (3) there was a positive and
\end{abstract}




\section{Chemistry Education Practice, 1(1), 2018 - 14}

Amin, Andayani, Sukib

significant relationship of both learning interests and learning habits towards learning achievements in chemistry as proven that Fcount (32.11) > Ftable (3.06).

Keywords: learning interests, learning habits, learning achievements in chemistry.

\section{PENDAHULUAN}

Berjalannya pendidikan tentunya tidak terlepas dari kegiatan belajar yang dilakukan baik di sekolah, di rumah, maupun lingkungan masyarakat. Proses belajar pada hakikatnya melibatkan perubahan yang terjadi dalam diri seseorang setelah berakhirnya aktivitas belajar. Perubahan tersebut salah satunya dapat dilihat dari hasil belajar siswa yang dapat dinyatakan dalam bentuk angka ataupun huruf.

Banyak faktor yang dapat mempengaruhi belajar siswa, faktor tersebut juga turut berpengaruh terhadap hasil belajar siswa. Secara umum faktor yang dimaksud digolongkan menjadi dua yaitu faktor internal dan faktor eksternal. Faktor internal merupakan faktor yang ada dalam diri individu yang sedang belajar, sedangkan faktor eksternal merupakan faktor yang ada di luar individu. Faktor internal yang dapat mempengaruhi hasil belajar salah satunya yaitu minat. Minat terkait dengan perasaan ingin tahu, mempelajari, mengagumi, atau memiliki sesuatu (Djaali, 2014).

Perilaku yang menunjukkan adanya minat seseorang dalam belajar yaitu: ada rasa suka dan senang pada sesuatu yang diminati, mempunyai kecenderungan yang tetap untuk memperhatikan dan mengenang sesuatu yang dipelajari secara terus menerus, ada rasa ketertarikan pada aktivitas-aktivitas yang diminati, lebih menyukai suatu hal yang menjadi minatnya daripada yang lainnya serta ditunjukkan melalui partisipasi pada aktivitas dan kegiatan (Slameto, 2015). Adanya minat belajar cenderung mengakibatkan siswa bersedia untuk meninggalkan kegiatan yang kurang mendukung kegiatan belajarnya. Siswa dengan minat belajar akan berusaha lebih keras serta pantang menyerah dalam menghadapi tantangan dalam belajar (Lestari, 2015).
Selain minat, faktor internal lainnya yang turut mempengaruhi hasil belajar siswa yaitu kebiasaan belajar baik di sekolah maupun di rumah. Banyak siswa yang tidak mendapatkan hasil belajar yang baik karena tidak mengetahui bagaimana cara belajar yang efektif. Kebiasaan belajar merupakan tingkah laku siswa secara teratur dan berulang-ulang dalam kegiatan belajarnya untuk mencapai tujuan yang diinginkan, terkait dengan cara menerima pelajaran, membaca buku, mengerjakan tugas, dan pengaturan waktu untuk menyelesaikan kegiatan (Djaali, 2014; Syah, 2011). Lebih lanjut, uraian kebiasaan belajar yang dapat mempengaruhi hasil belajar siswa meliputi pembuatan jadwal dan pelaksanaannya, membaca dan membuat catatan, mengulangi bahan pelajaran, konsentrasi serta mengerjakan tugas (Slameto, 2105). Adanya kebiasaan belajar yang efektif akan membantu siswa untuk mendapatkan hasil belajar yang baik karena semakin baik kebiasaan belajar siswa maka semakin baik pula prestasi akademik yang diraih (Khurshid, 2012).

Berdasarkan hasil wawancara yang dilakukan peneliti dengan beberapa guru kimia serta siswa kelas XI IPA di SMAN 2 Mataram dan SMAN 7 Mataram diperoleh informasi bahwa minat belajar kimia siswa bervariasi. Ada siswa yang memiliki minat belajar yang tinggi, sedang, maupun rendah. Tinggi maupun rendahnya minat belajar siswa salah satunya dapat dilihat dari perilaku siswa ketika pembelajaran berlangsung di dalam kelas. Selama berlangsungnya proses pembelajaran, hanya beberapa siswa yang terlihat sangat antusias untuk belajar. Siswa yang antusias belajar aktif menjawab pertanyaan yang diberikan guru serta bertanya terkait dengan materi yang masih belum dipahami. Sementara itu, siswa yang kurang tertarik untuk belajar cenderung kurang memperhatikan 
penjelasan guru saat sedang menyampaikan materi pelajaran.

Hasil wawancara dengan siswa juga menunjukkan bahwa kebiasaan belajar siswa bervariasi, khusunya kebiasaan belajar siswa di luar jam sekolah. Saat berada di rumah, ada siswa yang belajar secara teratur sesuai dengan jadwal belajarnya dan ada juga siswa yang belajar kurang teratur yakni belajar ketika ada tugas yang diberikan guru, bahkan ada juga siswa yang hanya belajar ketika mendekati ulangan atau ujian.

Sama halnya dengan minat belajar dan kebiasaan belajar, hasil belajar kimia siswa kelas XI berdasarkan perolehan ulangan tengah semester ganjil tahun ajaran 2017/2018 menunjukkan bahwa ada siswa yang memperoleh hasil belajar yang sangat tinggi, sedang, dan ada juga siswa yang memperoleh hasil belajar yang rendah. Namun, secara umum masih banyak siswa klasifikasi skor yang digunakan mengacu pada tabel 1 (Nurkancana \& Sumartana, 2010).

Berdasarkan masalah yang telah dipaparkan, maka peneliti tertarik untuk mengadakan penelitian terkait dengan hubungan antara minat belajar dan kebiasaan belajar terhadap hasil belajar kimia siswa kelas XI IPA SMA Mataram tahun ajaran 2017/2018.

\section{METODOLOGI PENELITIAN}

Penelitian ini telah dilaksanakan di SMAN 2 Mataram dan SMAN 7 Mataram pada semester II (genap) tahun ajaran 2017/2018 yang terdiri dari 3 tahapan, yakni 1) persiapan, 2) pelaksanaan penelitian dan 3) pengolahan data. Penelitian ini merupakan jenis penelitian kuantitatif dengan rancangan korelasional yang bertujuan untuk mengetahui ada atau tidaknya hubungan antara dua atau beberapa variabel [6]. Adapun variabel yang digunakan pada penelitian ini yaitu minat belajar, kebiasaan belajar dan hasil belajar kimia siswa.

Populasi penelitian yaitu seluruh siswa kelas XI IPA di SMAN 2 Mataram dan
SMAN 7 Mataram yang terdiri dari 336 siswa dan sampel penelitian sebanyak 170 siswa ditentukan dengan tehnik proportionate stratified random sampling. Teknik pengumpulan data yaitu menggunakan angket dan dokumentasi dimana terlebih dahulu dibuat instrumen yang telah diuji validitas serta reliabilitasnya [6]. Selanjutnya, tehnik analisis data yang digunakan yaitu analisis korelasi sederhana, korelasi ganda, regresi sederhana, serta regresi ganda. Namun, sebelumnya dilakukan analisis deskriptif berupa klasifikasi skor tingkat minat belajar, kebiasaan belajar dan hasil belajar kimia siswa serta perhitungan persentase pada setiap aspek maupun indikator variabel minat belajar dan kebiasaan belajar. Adapun pedoman klasifikasi skor yang digunakan mengacu pada tabel 1 (Nurkancana \& Sumartana, 1990).

Tabel 1. Pedoman Konversi Skor Skala 5

\begin{tabular}{ccc}
\hline No & Kriteria & Kategori \\
\hline 1 & $\mathrm{M}_{\mathrm{k}}+1,5 \mathrm{SD}_{\mathrm{k}}<\mathrm{X} \leq$ & $\begin{array}{c}\text { Sangat } \\
\text { tinggi }\end{array}$ \\
\hline 2 & $\mathrm{M}_{\mathrm{k}}+0,5 \mathrm{SD}_{\mathrm{i}}<\mathrm{X} \leq \mathrm{M}_{\mathrm{k}}+$ & Tinggi \\
& $1,5 \mathrm{SD}_{\mathrm{k}}$ & \\
\hline 3 & $\mathrm{M}_{\mathrm{k}}-0,5 \mathrm{SD}_{\mathrm{k}}<\mathrm{X} \leq \mathrm{M}_{\mathrm{k}}+$ & Sedang \\
& $0,5 \mathrm{SD}_{\mathrm{k}}$ & \\
\hline 4 & $\mathrm{M}_{\mathrm{k}}-1,5 \mathrm{SD}_{\mathrm{k}}<\mathrm{X} \leq \mathrm{M}_{\mathrm{k}}-$ & Rendah \\
& $0,5 \mathrm{SD}_{\mathrm{k}}$ & \\
\hline 5 & $\mathrm{Smin}_{\mathrm{i}}<\mathrm{X} \leq \mathrm{M}_{\mathrm{k}}-1,5 \mathrm{SD}_{\mathrm{k}}$ & $\begin{array}{c}\text { Sangat } \\
\text { rendah }\end{array}$ \\
\hline
\end{tabular}

$\begin{aligned} \text { Keterangan: } & \\ \mathrm{Mk} & =\text { mean kombinasi } \\ \mathrm{Ma} & =\text { mean ideal } \\ \mathrm{Ma} & =\text { mean aktual } \\ \mathrm{Smaks}_{\mathrm{i}} & =\text { skor maksimal ideal } \\ \mathrm{Smin}_{\mathrm{i}} & =\text { skor minimal ideal } \\ \mathrm{SDk} & =\text { standar deviasi kombinasi } \\ \mathrm{SDa} & =\text { standar deviasi aktual }\end{aligned}$

\section{HASIL DAN PEMBAHASAN}

Hasil analisis data menunjukkan bahwa terdapat hubungan yang positif dan signifikan antara minat belajar terhadap hasil belajar kimia siswa kelas XI IPA SMA Mataram tahun ajaran 2017/2018 yang ditunjukkan oleh nilai $\mathrm{r}_{\text {hitung }}$ sebesar 0,518 lebih besar dari $\mathrm{r}_{\text {tabel }}$ sebesar 0,159 pada taraf signifikan 5\% dengan jumlah sampel 
sebanyak 170. Besarnya koefisien korelasi menunjukkan tingkat hubungan tergolong sedang. Artinya, jika minat belajar siswa meningkat maka hasil belajar kimia siswa juga meningkat. Hasil penelitian ini didukung oleh Astuti yang menyatakan bahwa semakin baik minat belajar siswa maka semakin baik pula prestasi belajar yang diperoleh [8].

Peningkatan hasil belajar kimia siswa ketika variabel minat belajar divariasikan nilainya dapat di prediksikan menggunakan persamaan regresi yang diperoleh yaitu $\mathrm{Y}=18,74+0,616 \mathrm{X}$. Koefisien regresi sebesar 0,616 menyatakan bahwa setiap peningkatan 1 poin variabel minat belajar siswa maka hasil belajar siswa akan mengalami peningkatan sebesar 0,616. Hasil angket menunjukkan bahwa minat belajar siswa secara keseluruhan termasuk dalam kategori tinggi. Setiap aspek minat belajar sudah termasuk dalam kategori baik. Adapun rincian setiap aspek minat belajar dapat dilihat pada tabel 2 .

\section{Tabel 2 Hasil Angket Minat Belajar Setiap Aspek.}

Data pada tabel 2 menunjukkan bahwa persentase tertinggi diperoleh pada aspek perhatian sedangkan persentase terendah diperoleh pada aspek rasa tertarik. Selain itu, setiap indikator minat belajar juga sudah tergolong baik. Rincian data hasil angket minat belajar pada setiap indikator dapat dilihat pada tabel 3 .
Tabel 3. Hasil Angket Minat Belajar Setiap Indikator

\begin{tabular}{llc}
\hline No & \multicolumn{1}{c}{ Indikator } & $\begin{array}{c}\text { Persentase } \\
(\%)\end{array}$ \\
\hline 1. & $\begin{array}{l}\text { Ketertarikan siswa pada } \\
\text { pelajaran kimia }\end{array}$ & 60,59 \\
\hline 2. & $\begin{array}{l}\text { Ketertarikan siswa pada } \\
\text { guru kimia }\end{array}$ & 61,47 \\
\hline 3. & $\begin{array}{l}\text { Mendengarkan dan } \\
\text { memperhatikan } \\
\text { penjelasan guru }\end{array}$ & 66,47 \\
\hline 4. & $\begin{array}{l}\text { Terlibat secara aktif } \\
\text { selama pembelajaran } \\
\text { berlangsung }\end{array}$ & 62,97 \\
\hline 5. & $\begin{array}{l}\text { Mengerjakan tugas } \\
\text { dengan baik }\end{array}$ & 66,43 \\
\hline 6. & $\begin{array}{l}\text { Kesadaran akan adanya } \\
\text { manfaat }\end{array}$ & 62 \\
\hline 7. & $\begin{array}{l}\text { Keinginan untuk } \\
\text { berprestasi }\end{array}$ & 64,53 \\
\hline
\end{tabular}

Data pada tabel 3 menunjukkan bahwa selisih antara setiap indikator tidak terlalu tinggi. Persentase tertinggi diperoleh pada indikator mendengarkan dan memperhatikan penjelasan guru sedangkan persentase terendah diperoleh pada indikator ketertarikan siswa pada

\begin{tabular}{|l|l|l|}
\hline No & Aspek & Presentase \\
\hline 1. & Rasa tertarik & 60,81 \\
\hline 2. & Perhatian & 66,47 \\
\hline 3. & Partisipasi & 64,51 \\
\hline 4. & $\underline{\text { Keinginan/kesadaran }}$ & 63,14 \\
\hline
\end{tabular}

pelajaran kimia.

Sementara itu, data hasil belajar siswa menunjukkan bahwa hasil belajar kimia siswa termasuk dalam kategori sedang. Hal ini menandakan bahwa masih belum optimalnya minat belajar siswa sehingga diperlukan berbagai upaya meningkatkan minat belajar, khususnya pada aspek rasa tertarik dengan harapan agar hasil belajar kimia siswa yang selanjutnya menjadi lebih baik. Beberapa upaya yang dapat dilakukan untuk meningkatkan minat belajar siswa diantaranya yaitu menggunakan berbagai metode mengajar (Sardiman, 2011), menyampaikan pelajaran secara menarik dan 
menyenangkan, mengaitkan bahan pelajaran dengan peristiwa yang terjadi di lingkungan sekitar serta menguraikan kegunaannya bagi siswa di masa yang akan datang (Slameto, 2015).

Variabel minat belajar pada penelitian ini memberikan kontribusi terhadap hasil belajar kimia siswa yakni sebesar $26,83 \%$ sedangkan sisanya sebesar $73,13 \%$ dipengaruhi oleh faktor-faktor lain yang tidak diteliti dalam penelitian ini. Faktor-faktor lain yang dimaksud dapat berupa faktor jasmaniah, faktor keluarga, faktor sekolah, maupun masyarakat.

Sementara itu, hasil analisis data juga menunjukkan bahwa terdapat hubungan yang signifikan antara kebiasaan belajar terhadap hasil belajar kimia siswa kelas XI IPA SMA Mataram tahun ajaran 2017/2018 yang ditunjukkan oleh nilai $r_{\text {hitung }}$ sebesar 0,476 lebih besar dari $r_{\text {tabel }}$ sebesar 0,159 pada taraf signifikan 5\% dengan jumlah sampel sebanyak 170. Besarnya koefisien korelasimenunjukkan tingkat

hubungan tergolong sedang. Hasil penelitian ini sesuai dengan pernyataan Djaali dan Aunurrahman bahwa kebiasaan belajar dapat mempengaruhi hasil belajar siswa (Syah, 2011; Aunurrahman, 2011). Lebih lanjut, Khursyid et al. (2012) dan Zakiyah (2016) dalam penelitiannya juga menyebutkan ada korelasi positif antara kebiasaan belajar terhadap hasil belajar siswa. Semakin baik kebiasaan belajar siswa maka semakin baik pula hasil belajar yang diperoleh.

\section{Peningkatan hasil belajar kimia siswa} apabila variabel kebiasaan belajar divariasikan nilainya dapat di prediksikan menggunakan persamaan regresi yang diperoleh yaitu $\mathrm{Y}=27,386+0,525 \mathrm{X}$. Koefisien regresi sebesar 0,525 menyatakan bahwa setiap kenaikan 1 poin variabel kebiasaan belajar maka hasil belajar siswa mengalami peningkatan sebesar 0,525.

Hasil angket menunjukkan kebiasaan belajar siswa secara keseluruhan tergolong sedang. Hal ini dapat dilihat dari metode kerja dalam belajar serta kesigapan siswa dalam belajar, meliputi tata cara pada saat mengikuti pelajaran, belajar kelompok maupun individu, pembuatan jadwal dan pelasanaan, membaca dan membuat catatan, mengulangi bahan pelajaran, konsentrasi serta mengerjakan tugas. Aspek metode kerja dalam belajar tergolong cukup baik dengan persentase sebesar 58,74\% dan aspek kesigapan dalam belajar tergolong baik dengan persentase sebesar $65,55 \%$. Lebih lanjut, jika ditinjau dari setiap indikator diketahui bahwa cara mengikuti pelajaran, cara kerja kelompok, cara belajar individu, serta mengulangi bahan pelajaran termasuk dalam kategori cukup sedangkan indikator lainnya yaitu pembuatan jadwal dan pelaksanaan, membaca dan membuat catatan, konsentrasi serta mengerjakan tugas termasuk dalam kategori baik. Persentase setiap indikator dapat dilihat pada tabel 4.

Tabel 4. Hasil Angket Kebiasaan Belajar Setiap Indikator

\begin{tabular}{clc}
\hline No & \multicolumn{1}{c}{ Indikator } & $\begin{array}{c}\text { Persentase } \\
(\%)\end{array}$ \\
\hline 1. & Cara mengikuti pelajaran & 59,31 \\
\hline 2. & Cara kerja kelompok & 50,39 \\
\hline 3. & Cara belajar individu & 55,35 \\
\hline 4. & $\begin{array}{l}\text { Pembuatan jadwal dan } \\
\text { pelaksanaan }\end{array}$ & 62,89 \\
\hline 5. & $\begin{array}{l}\text { Membaca dan membuat } \\
\text { catatan }\end{array}$ & 62,88 \\
\hline 6. & $\begin{array}{l}\text { Mengulangi bahan } \\
\text { pelajaran }\end{array}$ & 59,31 \\
\hline 7. & Konsentrasi & 69,12 \\
\hline 8. & Mengerjakan tugas & 64,36 \\
\hline
\end{tabular}

Data pada tabel 4 menunjukkan bahwa persentase tertinggi diperoleh pada indikator konsentrasi sedangkan persentase terendah diperoleh pada indikator cara kerja kelompok. Hal ini menunjukkan bahwa kebiasaan belajar siswa masih belum optimal sehingga diperlukan adanya upaya untuk meningkatkan kebiasaan belajar siswa, khususnya terkait dengan cara kerja kelompok dengan harapan agar hasil belajar yang diperoleh siswa menjadi lebih baik. Variabel kebiasaan belajar dalam penelitian ini memberikan kontribusi terhadap hasil belajar kimia siswa sebesar $22,66 \%$ dan sisanya sebesar $77,34 \%$ dipengaruhi oleh faktor-faktor lain yang tidak diteliti dalam penelitian ini.

Selain itu, hasil analisis korelasi ganda menunjukkan bahwa terdapat 
hubungan yang positif dan signifikan antara minat belajar dan kebiasaan belajar secara bersama-sama terhadap hasil belajar kimia siswa yang dibuktikan dengan nilai Fhitung yang diperoleh sebesar 32,11 lebih besar dari $\mathrm{F}_{\text {tabel }}$ sebesar 3,06 pada taraf signifikan 5\% serta nilai koefisien korelasi ganda sebesar 0,527 . Besarnya koefisien korelasi ganda menunjukkan tingkat hubungan tergolong sedang. Artinya, jika minat belajar dan kebiasaan belajar siswa meningkat maka hasil belajar siswa juga meningkat. Hasil penelitian ini didukung oleh Siagian yang menyatakan bahwa minat dan kebiasaan belajar secara bersama-sama berpengaruh terhadap prestasi belajar siswa. Apabila minat belajar dan kebiasaan belajar siswa tinggi maka akan tinggi pula prestasi belajar yang diraih siswa (Siagian, 2015).

Peningkatan hasil belajar kimia siswa apabila variabel minat belajar dan kebiasaan belajar divariasikan nilainya dapat di prediksikan menggunakan persamaan regresi yang diperoleh yaitu $\mathrm{Y}=17,6+0,457 \mathrm{X}_{1}+$ $0,182 X_{2}$. Koefisien regresi sebesar 0,457 menyatakan bahwa setiap peningkatan 1 poin siswa akan mengalami peningkatan sebesar 0,457 dan koefisien regresi sebesar 0,182 menyatakan bahwa setiap peningkatan 1 poin variabel kebiasaan belajar, maka hasil belajar siswa akan mengalami peningkatan sebesar 0,182 . Minat belajar dan kebiasaan belajar secara bersama-sama memberikan kontribusi terhadap hasil belajar kimia siswa sebesar $27,77 \%$ sedangkan sisanya sebesar $72,23 \%$ dipengaruhi oleh faktor lain yang tidak diteliti pada penelitian ini.

\section{KESIMPULAN}

Berdasarkan hasil dan pembahasan, maka dapat disimpulkan hal-hal sebagai berikut:

1. Terdapat hubungan yang positif dan signifikan antara minat belajar terhadap hasil belajar kimia siswa kelas XI IPA SMA Mataram tahun ajaran 2017/2018

2. Terdapat hubungan yang positif dan signifikan antara kebiasaan belajar terhadap hasil belajar kimia siswa kelas XI IPA SMA Mataram tahun ajaran 2017/2018
3. Terdapat hubungan yang positif dan signifikan antara minat belajar dan kebiasaan belajar secara bersama-sama terhadap hasil belajar kimia siswa kelas XI IPA SMA Mataram tahun ajaran 2017/2018

\section{UCAPAN TERIMA KASIH}

Penulis mengucapkan terimakasih kepada dosen pendidikan kimia FKIP Universitas Mataram untuk bimbingan dan arahan selama penelitian serta pihak sekolah SMAN 2 Mataram dan SMAN 7 Mataram untuk ijin pelaksanaan penelitian.

\section{DAFTAR PUSTAKA}

Astuti, S. P. (2015). Pengaruh Kemampuan Awal dan Minat Belajar terhadap Prestasi Belajar Fisika. Jurnal Ilmiah Pendidikan MIPA, 5(1), 68-75.

Aunurrahman. (2011). Belajar dan Pembelajaran. Bandung: Alfabeta.

Djaali. (2014). Psikologi Pendidikan. Jakarta: Bumi Aksara.

Khurshid, F., Tanveer, A., \& Qasmi, F. N. (2012). Relationship between Study Habits and Academic Achievement among Hostel Living and Day Scholars' University Students. British Journals of Humanities and Social Sciences, 3(2), 33-42.

Lestari, I. (2015). Pengaruh Waktu Belajar dan Minat Belajar Terhadap Hasil Belajar Matematika. Jurnal Ilmiah Pendidikan MIPA, 3(2), 115-125.

Nurkancana, W. dan Sumartana. (1990). Evaluasi Pendidikan. Surabaya: Usaha Nasional.

Sardiman, A. M. (2011). Interaksi dan Motivasi Belajar Mengajar. Jakarta: Rajawali Pers.

Siagian, R. E. F. (2015). Pengaruh Minat dan Kebiasaan Belajar Siswa terhadap Prestasi Belajar Matematika. Jurnal Ilmiah Pendidikan MIPA, 2(2), 122-131.

Slameto. 2015. Belajar dan Faktor-Faktor yang Mempengaruhinya. Jakarta: Rineka Cipta.

Sugiyono. (2013). Metode Penelitian Pendidikan, Pendekatan Kuantitatif, 


\section{Chemistry Education Practice, 1(1), 2018 - 19}

Amin, Andayani, Sukib

Kualitatif dan $R \quad \& \quad D$. Bandung: Alfabeta.

Syah, M. (2011). Psikologi Pendidikan dengan Pendekatan Baru Edisi Revisi. Bandung: PT Remaja Rosda Karya.
Zakiyah, A. F. (2016). Hubungan antara Kebiasaan Belajar dengan Hasil Belajar Siswa di Kelas IV SDN Gugus Muwardi Kecamatan Kaliwungu. Skripsi. Universitas Negeri Semarang. 